\title{
The Profile of the Moroccan Entrepreneur: The New Generation of Entrepreneurs in Morocco
}

\author{
Boutayna Ibn Cheikh \\ $\mathrm{PhD}$ student at University Mohamed V-Rabat, Morocco \\ Lalla Latifa Alaoui \\ Professor at University Mohamed V- Rabat, Morocco
}

Doi:10.19044/esj.2018.v14n19p90 URL:http://dx.doi.org/10.19044/esj.2018.v14n19p90

\begin{abstract}
The present paper is the core of a study carried out based on a survey of 113 Moroccan entrepreneurs belonging to the new generation, not only because of its age (25-45 years), but also and especially in particular its citizens' behavior, economic patriotism, investment in risk areas and contribution to the national effort of innovation, training and modernization of industrial relations. According to this study, we can understand the roots of the Moroccan elite, and the new economic elite in its relation to the stakes of the reform that has lived in modern Morocco, and analyze the mutations. Each criteria has been crowned by a series of testimonies collected from a sample of entrepreneurs and representatives of the general administration, although belonging to various geographical, ethnic, social and professional horizons, but most often animated by an only goal: to help build a winning Morocco. At the end of this study, We have sketched out a model of the new generation of entrepreneurs "The elitist entrepreneur." It would be pretentious to clarify the realities of entrepreneurship in Morocco are of great complexity.
\end{abstract}

Keywords: Entrepreneurship, Morocco, elite, economy, Moroccan entrepreneur profile

\section{Introduction}

The act of entrepreneurship is vital as much as it constitutes a formidable way of self-realization and promotes a more collective movement of economic wealth creation.

This paper aims to explore and deepen the problem of the current role of the Moroccan "Entrepreneur" faced with constraints or opportunities determined by a political context largely defined by a Moroccan state of Makhzen. 
Morocco, a young country, engaged in the path of liberalism, openness and democratization, is today experiencing important sociocultural, demographic, legislative and economic changes. Moroccan companies do not remain on the margins of these mutations they also live profound jolts. They are constrained to adapt their organization constantly to changes, to modernize to survive, develop and respond to new market demands.

The paper research answers the question about the sociodemographic profile of the Moroccan entrepreneur furthermore leads to several questions which seem to us to be fundamental:

- What are the historical and socio-cultural foundations of the emergence of the Moroccan economic elite?

- What is the impact of Morocco's economic reforms since independence on entrepreneurs and businesses?

- What is the transformation of entrepreneurship and business in Morocco?

The first chapter of this paper is based on a preliminary reflection on the genesis of a Moroccan economic elite, as well as on the realities of entrepreneurship, impelled by the dynamics of the reforms that Morocco has experienced since its independence. This reflection was carried out on the basis of historical documents and research drawn from the existing literature on the subject.

The second part is the result of a survey of a sample of $\mathbf{1 1 3}$ entrepreneurs belonging to what we have described in this new generation brief. Their selection was carried out taking into account age, gender approach, classification of this category of population by region of activity, and their categorization according to the influence of the Environment, in particular the difficulties encountered by business leaders.

This survey was also enriched by a series of views and experiences (Chapter 3) drawn from entrepreneurs and personalities "witnesses of their times"; some belonging to the generation of independence, known and recognized by their experiences and contributions to the national community in the field of entrepreneurship (case of BRAHIM ZNIBER) and others belonging to the new generation in perfect illustration (AZIZ AKHENNOUCH).

The purpose of these testimonies is to fertilize and enrich the results of the survey and to draw the most crucial lessons from the point of view of the direct actors' assessment of the changes that the Moroccan economy is experiencing in this field. It's decisive phase of its evolution and it's necessary to identify the challenges that the economic elites will have to face in order to contribute to the construction of modern Morocco. 


\section{Part 1:}

Theoretical approach to the Moroccan elite history, culture and reforms

Chapter I: Historical and Sociocultural Foundations of the Emergence of Entrepreneurship in Morocco

\section{Entrepreneurship in Morocco: The Genesis of Economic Development in Morocco}

The Entrepreneur has undergone an evolution since independence, and the country has seen the emergence of a class of businessmen who have invested in wealth-producing sectors: textile, agro-food and light industry. But these sectors can't constitute the foundations of a modern economy capable of creating wealth and engaging the country in a generalized economic and social development, due to the deep and dominant mentality of the Moroccan trader, cautious and cautious, saving without taking risk.[ Global Entrepreneurship Monitor. 2015. The Entrepreneurial Dynamics in Morocco]

This situation lasted until 1990, when major structural reforms were initiated which will be the source of the growth that Morocco has known until today. These reforms have led to some gradual changes, but some have spurred a real entrepreneurial dynamic. This dynamic has favored the genesis and development of several changes in the new generation of entrepreneurs. [GUERRAOUI and AFFAYA,2009].

\section{Types and forms of Moroccan entrepreneurship}

Entrepreneurship in Morocco is to admit the cohabitation of two categories, formal (opportunistic entrepreneurship) and informal (forced entrepreneurship or necessity entrepreneurship).

The entrepreneurship of necessity, which very often comes under a form of self-employment "survival entrepreneurship." That is, a person ultimately has no choice but to create his own job usually at home.

Opportunistic entrepreneurship is a strategic intention of people who have already worked in other companies, and because they have identified a market opportunity, decide to start their own business. Generally, they are people with extensive experience and capital, which is sometimes as important as financial capital.

Certainly, entrepreneurship in Morocco benefits from a certain democratization. Indeed, the constitution provides freedom of enterprise and reserve to all citizens. However, in a context full of challenges, the association agreement with foreign payers, cumbersome administrative procedures, lack of funding etc., requires the upgrading of management practices, especially in small and medium-sized enterprises companies often run by the "m'allem ${ }^{5 "}$

\footnotetext{
${ }^{5}$ The owner of a small business in Morocco .
} 
(note that in Morocco, Small business account for more than $90 \%$ of the economic fabric). [GUERRAOUI and AFFAYA,2009]

In this context, types of entrepreneurship have emerged and have become very dominant in Morocco: cooperative, solidarity-based and incomegenerating activities. [ USAID,2012., Morocco Economic Competitiveness, Entrepreneurship]

In the vicinity and since the adoption of a structural adjustment program in 1983 and the launching of the vast privatization program, a new commercial and industrial bourgeoisie has emerged, with innovative economic and social dynamics: "Does the emergence of a new social group, private entrepreneurs, mean the beginning of an irreversible process of building a civil society that intends to assert itself and organize itself independently and autonomously?". (Tangeaoui,1993). This category is part of an intrigue of political change in Morocco under the banner of the "upgrade" agreements free exchange "EU" then "USA" recently with China under the legitimate transitory regularly convened and which is inscribed the narrative reformer with its heroes and against heroes, of which it seems that the entrepreneurs are figures of prow.

\section{The profile of the Moroccan entrepreneur}

\subsection{The economic behavior of the Moroccan entrepreneur}

From the independence to the present day, we can identify three generations of entrepreneurs, each category has a behavior forged by internal management constraints and those of the environment. [Morocco Country Commercial Guide. 2016, GUERRAOUI and AFFAYA,2009]

\subsubsection{First Generation Contractors}

They come from the mercantile bourgeoisie. They have important guarantees both on a personal and an institutional level:

- Land assets that can be entrusted to the banks as collateral for the granting of credits.

- A tariff and contingent policy that protects them from competition.

- Incentives: Investment tax exemption code.

- Adequate infrastructure.

This generation was not subject to financial problems, protectionist policy allowed it to establish itself in a position protected by customs barriers, reducing the effects of competition and thereby allowing it to realize significant profits and the creation of working capital and significant wealth. [ USAID,2012., Morocco Economic Competitiveness, Entrepreneurship]

At this level, there was a distinction between:

- The entrepreneur with a small production unit who considers that his role is limited to the administration of his business, the purchase of the factor 
production tool and the sale of the products obtained. He is entirely devoted to the life of his enterprise; ready at all times to cope with the difficulties that would arise in all the workings of his company.

- The entrepreneur, owner of a large company, is on the lookout for bargains, observes a careful attitude towards the environment.

Be that as it may; the first-generation entrepreneur observes dignity in the face of the accumulation of difficulties, refuses to go to the obvious and closes his factory, bankruptcy is banned, and he will continue to make efforts to maintain his honor except.

The characteristic features of the entrepreneur's behavior of this generation are: the short-term vision and the concern of the lowest costs and the greatest profits. These concerns are evident in the investment decision and management style. Flair and intuition give way to rational calculation in the investment decision.

Their attitude towards money is marked by the shortage of capital, even though large sums of money are diverted from the introductory sector to investment in land, commerce, and the creation of security stocks for speculative purposes. With regard to innovation, the entrepreneur of the first generation does not embrace the design of Schumpeter's innovative entrepreneur, whose constant concern is to realize new combinations of factors of production (Couple Product-market), new organization and methods. [GUERRAOUI and AFFAYA,2009]

Due to the entrepreneur confusion between the power of money and management and the relation of independence are established between him and his staff.

\subsubsection{Entrepreneurs of the 2 nd generation contractors}

The emergence of second-generation entrepreneurs was perceptible in the 1970s. It was encouraged by the existence of a productive fabric, internal competition, the development of financial intermediation (CIH, BNDE), and the creation of industrial groups (SCP, sugar factories, BRPM, etc.). These entrepreneurs are the result of skimming of the first generation who was sufficiently dynamic to seize the opportunities offered by the Moroccan policy, the positive impact of the protection policy on the financial resources of these companies and their allocation in diversification activities.

\subsubsection{Entrepreneurs of the 3rd generation}

Entrepreneurs of this generation constitute a diverse group of socioprofessional groups (administrative executives, middle managers of companies). They are characterized by a desire to overcome the difficulties of all kinds inherent to the act of creation, a spirit of competition sharpened and aggressive, a quasi-endemic shortage of financial resources. 
The financial behavior of this category of entrepreneurs is dominated by a double requirement that is not necessarily convergent: the need for external financing of growth because of the low level of capital and the imperative of financial autonomy.

The financial behavior of this category of entrepreneurs is dominated by a double requirement that is not necessarily convergent: the need for external financing of growth due to the low level of capital and the imperative of financial autonomy.

\subsection{Motivations of the Moroccan entrepreneur}

Three stimulating types guide Moroccan entrepreneur behavior: [(USAID), 2012. Morocco Economic Competitiveness, Entrepreneurship, High-Growth Entrepreneurship: a Preliminary Literature Review International Energy Agency, 2014]

\subsubsection{The search for social ascension}

The entrepreneur advocates activity for a need for social fulfillment.This is due to social rules in particular in the Berber and fassi social groups, the idler is frowned upon, bankruptcy is honored a high social status requires intense activity. Social motivation is a family reflection of the national entrepreneur (Provider of incomes, absence of family relationship). Social motivation grows with the development of the Society.

\subsubsection{Psychological considerations}

The dimension of self-realization and fulfillment is of paramount importance: the management of the company allows the entrepreneur to free himself from the weight of the hierarchy which has been able to mark his professional experience, to carry out his activity independently and to make ideas and concepts.

\subsubsection{Economic considerations}

The company is a source of material well-being and well-being for the family, due to the confusion between the patrimony and the wealth of the leader.The latter manages the success of the company to ensure the material ease of the enterprise of his family. The economic consideration may result from the desire to exploit an opportunity, to test the viability of an idea etc.

\section{Chapter II: The most important mutations of the Moroccan entrepreneurship}

The various mutations that undergo entrepreneurship in Morocco have been highlighted by Pr. AFFAYA and DRISS GUERRAOUI (20090) in their research that they conducted with the Moroccan companies. 


\section{Sociological and Cultural Mutations of Entrepreneurship in Morocco}

It follows from this survey (2009) that:

The main reason put forward by the entrepreneurs surveyed is the search for independence and freedom to act (39\% of cases), and this is where one of the great sociological and cultural changes in entrepreneurship in Morocco , that is to say that the choice to undertake by the entrepreneurs surveyed is not due to a difficulty to find a job but they preferred the path of entrepreneurship because of the conditions that Morocco currently offers to the sector private partnerships and their own initiative.

\section{Motivation: The main source of entrepreneurship}

The main source of entrepreneurship is the motivation. In fact, a person can't become entrepreneur by chance, instead he should first love his business; get motivated and be engaged in the entrepreneurial "adventure" to be able to succeed.

\section{Entrepreneurship, a vocation and the Influence of the Environment}

Two factors are paramount for an entrepreneur regardless of his level of training. The first is linked to experience in the field in which it intends to carry out its activity and the second relates to the capital needed to start up its business. These two factors must be accompanied by a firm will to undertake and support from family and relatives. Indeed, the company requires technical and financial means that cannot be acquired by chance.

Therefore, Entrepreneurs believe intelligence and good management, coupled with an entrepreneurial spirit and the ability to understand the environment in which their company operates, are also necessary to undertake.

Entrepreneurship failing to break with the family network: The results show that new generations of entrepreneurs find it hard to break with the family network to create their own businesses (59.2\% of entrepreneurs surveyed, $65,8 \%$ of women and $55 \%$ of men said they relied on help from family and banking institutions). ${ }^{6}$

\section{Chapter III: Views and opinions of stakeholders}

\section{Brahim Zniber's opinion}

One can become an entrepreneur by chance, it suffices to have in his depths a fierce will to succeed, a will that must be tempered by patience, when "the winds seem contrary".

- To give rise to a chance.Above all, not to be obsessed with lucre (a highly coveted profit), since profit must be the logical consequence of patiently constructed buildings.

\footnotetext{
${ }^{6}$ Bayt.com. 2016. Top Cities in the Middle East and North Africa Survey.
} 
-Creating a business in Morocco is certainly a promising act. It is also a difficult act for at least three reasons:

-any company naturally carries a share of risk

- there are still endogenous "burdens" in Morocco which do not allow the energies to be fully liberated

-the international environment is a source of multiple questions;

-according to B. Zniber, the first "recipe" is to have an "idea" that will become the thread of the company

-work, seriousness, perseverance, motivation and passion are "complementary and indispensable recipes".

In Morocco or elsewhere, kinship plays an important role in success. Brahim Zniber is personally optimistic about the possibility of undertaking in Morocco, notwithstanding (despite) the disadvantages that an entrepreneur may suffer, linked to the logic of clientelism and privileges. This translates into better governance at the intermediate and above all lower levels.

As for the Moroccan company's ability to cope with global competition, Brahim Zniber is aware of the need to open our economy, while appreciating the consequences in the medium term.

$\mathrm{He}$ is thinking of the "EMERGENCE" plan enriched since its launch, as it identifies, in a detailed way, the sectors of activity bearers in Morocco.

Regarding the question whether Morocco is really experiencing the emergence of a new generation of entrepreneurs and enterprises, the answer is Yes as far as the emergence of a large-scale enterprise is concerned, and even in the case of Small business, which are known to form the basis of an economy.

\section{Aziz Akhenouch's opinion}

Aziz Akhenouch has the firm conviction that the entrepreneur's stuff is first of all a feature of his personality. An intuitive personality, full of good energy, inspiration, audacity but also perseverance and rationality. A personality often built in adversity because often it is by crossing the difficulties of life, the even less pleasant experiences that we learn to go beyond our limits to grow.

According to him, if someone has to start today from nothing -scratch, he must lend a more attentive ear to the active market (a set of demands of what one asks or what one expects) of the consumer. Linking an offer to its real context is, on the other hand, paramount.

Many projects fail because they target lifestyles or thought that are out of line with current Moroccan reality. So this person has to apply to launch the right products on the cheap.

He also believes that the entrepreneur will need a good dose of boldness, initiative and flair in order to realize his project. 
With the right products, a well-targeted clientele, and a dose of leadership, we release the right energies to find strategic, organizational, operational and financial solutions.

Nevertheless, as far as the notions of difficulty and risk are concerned, they are, in his opinion, essential ingredients for any creation of a company, whether in Morocco or somewhere. [GUERRAOUI, AFFAYA,2009, Implementation of the "Small Business Act" for Europe in the Mediterranean Middle East and North Africa, 2014]

\section{Comparison between the two generations of these actors}

This act therefore remains risky for Small business which must approach their market. Therefore, successful business is a blend of daring, leadership, conviction, deep knowledge of each part of the company, a clear vision, a good control of risks, a perseverance to any test. The ultimate goal being to offer the right product at the cheap with good service. [ GUERRAOUI, AFFAYA,2009]

The State should promote the emergence of economic actors by improving the economic, legal and fiscal environment on the one hand, and by giving visibility to the strategic sectors on the other, and by encouraging the creation of leaders and locomotive companies in each of these sectors. In short, the State must instill the right dynamic while continuing to improve the sectoral framework.

Aziz Akhenouch thinks that an entrepreneur is first and foremost a citizen who contributes on his scale to the construction and the smooth running of his country.

According to him, Morocco's remarkable geographical position on which we can rely to develop projects with considerable margins really knows the emergence of a new generation of entrepreneurs and companies.

\section{Part 2:}

\section{Presentation and analysis of the survey with Moroccan entrepreneurs}

\section{Results of a survey}

\section{Survey by interview on the basis of a questionnaire}

\subsection{Definition of the questionnaire concept}

The questionnaire is the practical expression of the theoretical body. It remains now the technique most used in the study of representations. It presupposes a choice, a selection made by the researcher himself and concerning the topics tackled.

This Questionnaire (1) is given to learners as part of an entrepreneurial culture awareness course; so that they can give an idea of the type of activity of these Entrepreneurs. 


\subsection{Target and sample size}

The results presented in this thesis are the result of the 113 interviews conducted by the students of this year's promotion (2012/2013), which were expected to interview an average of 2 company managers per team of 56 male and female students on the basis of the questions that we have asked the interviewers and four of which are conducted by the Author in order to get an idea of the profile of the servants of their choice using voice recordings and cameras.

\subsection{Survey tool and processing business leaders' responses}

The interviews were completed with an average duration of 20 minutes. These 113 interviews were subsequently computer-processed and statistically interpreted by SPHINX software (2). The collection of maintenance responses is done by a quick input, processing and analysis on the software, something that took us in terms of a little time-after 40 hours of work.

\section{What is an interview survey?}

\subsection{Definition of maintenance}

Maintenance is above all a technique that results in the production of a discourse, the latter is a complex activity characterized by certain aspects that make analysis difficult.

\subsection{Survey by directional interview and its usefulness}

The survey by interview the questioning here is more refined, the themes of interview used speak more to the respondents because they refer to their experience.

This type of maintenance in general is longer, denser because more reflective and more mature. These interviews serve to test hypotheses and prove what is being advanced. We try to dig deep the information that is given, and to make the most of what the interlocutor says. This is the main analysis material. This type of interview also serves to deepen its problematic or to reshape it.

\subsection{The target and technique of this type of maintenance}

The interview survey is aimed at fewer people than a questionnaire survey and the relational dimension is much more present. The interview takes the form of a conversation, directed by the interviewer, about the study. The interviewer asks questions, adapts the form, order and content to the interviewee. 


\section{Classification by entrepreneurs Sex:}

This is the most common aspect of the literature. Knowledge of the profile and characteristics of business executives in Morocco is essential. The importance of this variable lies in its influence on entrepreneurial career. The profile of the entrepreneur in Morocco is as follows:

$=>35.39 \%$ are the work of Women and $\mathbf{6 4 . 6 0 \%}$ of Men.

\begin{tabular}{|l|r|r|}
\hline Sexe & Nb Cité & Fréquence \\
\hline Homme & 73 & $64,60 \%$ \\
\hline Femme & 40 & $35,39 \%$ \\
\hline Total & 113 & $100 \%$ \\
\hline
\end{tabular}

Source: authors

Figure 1: Classification by Their Sex

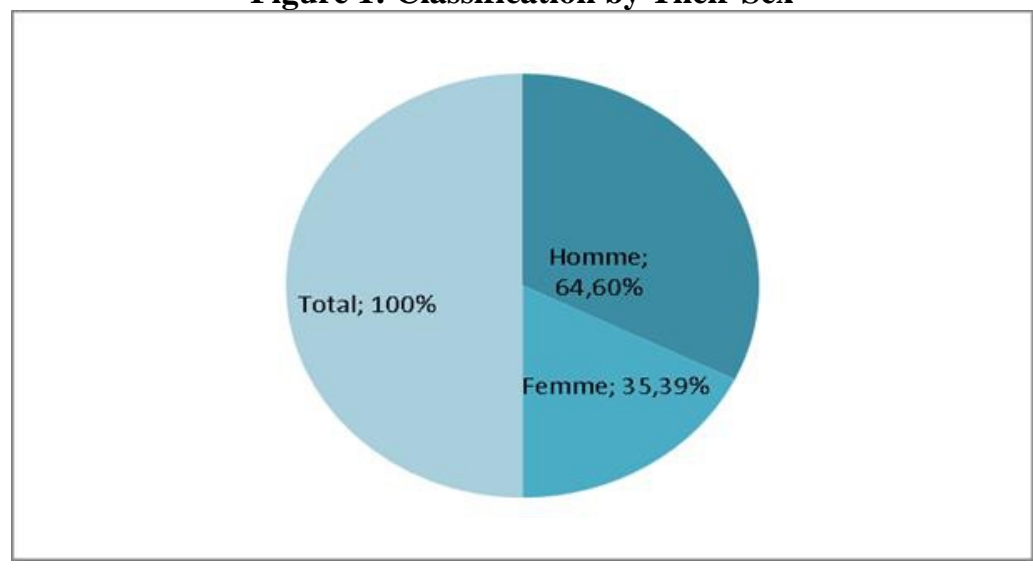

2. The distribution by the geographical location of the entrepreneur:

More than $3 / 4$ of the companies created are domiciled in the region "Rabat-Salé, Zemour Zair" with a volume percentage of $92.03 \%$; with respect to a low percentage rate for the other 12 regions of Morocco as an example; Agadir, Marrakech, Casablanca, etc.

\begin{tabular}{|l|l|l|r|}
\hline & & \\
\hline & Localisation géograph & Nb Cit & Fréquence \\
\hline Rabat-Salé Zemour Zai & 104 & $92,03 \%$ \\
\hline Autres régions du Mar & 9 & $7,96 \%$ \\
\hline Total & 113 & $100 \%$ \\
\hline
\end{tabular}

Source: authors 
Figure2: Division by the geographical location of the entrepreneur

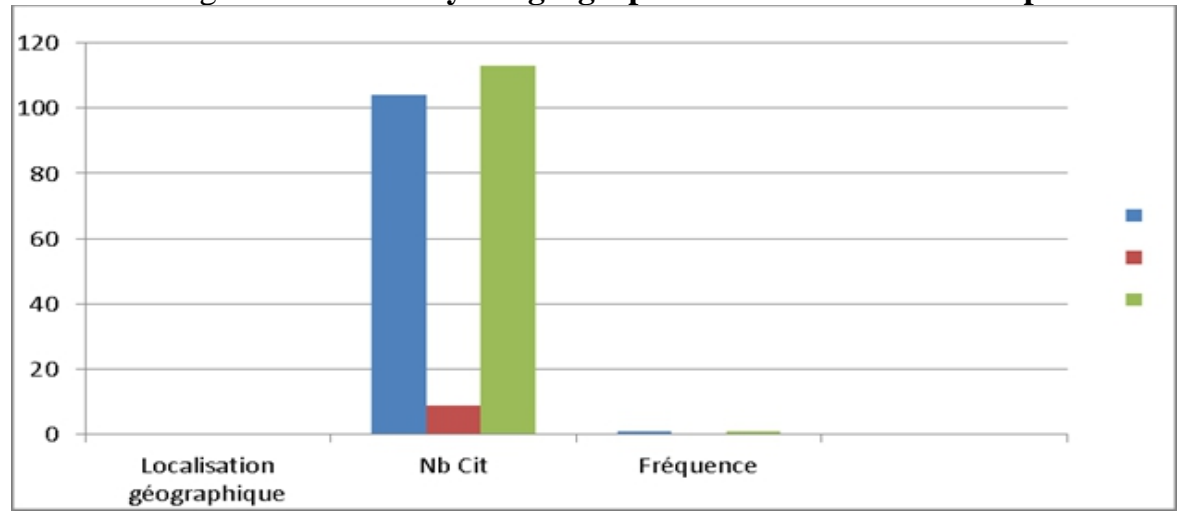

\section{The division by the entrepreneur's education level}

Regarding the training component, almost $88.7 \%$ of entrepreneurs surveyed have a higher level of education. This level of education is revealed at the level of the diplomas, since $5.3 \%$ have a $\mathrm{PhD}$, 25.6\% have a Master, 29.2\% have a Bachelor. The rest is backed by Associate degree (3.5\%), technicians (3.5\%), Highschool degree (4.4\%), and other representative profiles (graduated in electricity, computer science and accounting, catering, patent, designer).

\begin{tabular}{|l|l|l|}
\hline Bachelor degree & 33 & $\mathbf{2 9 , 2 0 \%}$ \\
\hline Master degree & 29 & $\mathbf{2 5 , 6 0 \%}$ \\
\hline Below High school or GED & 10 & $\mathbf{8 , 8 0 \%}$ \\
\hline PhD & 6 & $\mathbf{5 , 3 0 \%}$ \\
\hline Highschool degree & 5 & $\mathbf{4 , 4 0 \%}$ \\
\hline Associate degree & 4 & $\mathbf{3 , 5 0 \%}$ \\
\hline Non-degreed & 4 & $\mathbf{3 , 5 0 \%}$ \\
\hline Technician & 4 & $\mathbf{3 , 5 0 \%}$ \\
\hline$<$ BAC & 6 & $\mathbf{5 , 4 0 \%}$ \\
\hline Others profils & 12 & $\mathbf{0 , 9 0 \%}$ \\
\hline
\end{tabular}

Source: authors

Figure 3: The division by the entrepreneur's education level

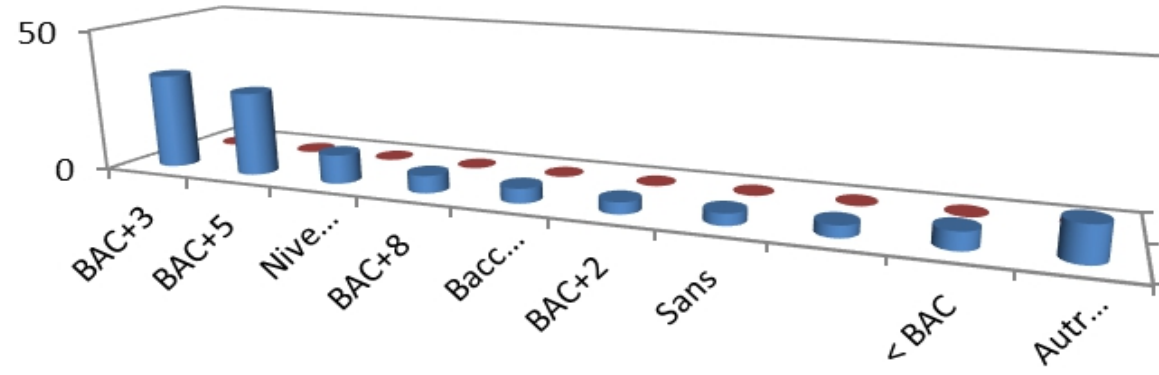




\section{The division by their activity}

This dimension of the profile of the entrepreneurs surveyed appears at the level of the choice of the domains that they consider to be conducive to business in Morocco. However, the most activity areas mentioned by the entrepreneurs surveyed concern: Agriculture, food, vital fields (health, education), services, IT, Real estate, training, telecommunications and advertising, others of low percentage.

\begin{tabular}{|l|l|l|}
\hline Services & 25 & $\mathbf{2 2 , 1 0 \%}$ \\
\hline IT & 12 & $\mathbf{1 0 , 6 0 \%}$ \\
\hline Jobs & 13 & $\mathbf{1 1 , 5 0 \%}$ \\
\hline Construction & 8 & $\mathbf{7 , 1 0 \%}$ \\
\hline Advertising et Communication & 9 & $\mathbf{8 , 0 0 \%}$ \\
\hline Education & 6 & $\mathbf{5 , 3 0 \%}$ \\
\hline Natural Product & 6 & $\mathbf{5 , 3 0 \%}$ \\
\hline Import/Export & 33 & $\mathbf{2 , 6 6 \%}$ \\
\hline
\end{tabular}

Figure4: The division by their activity

Source: authors

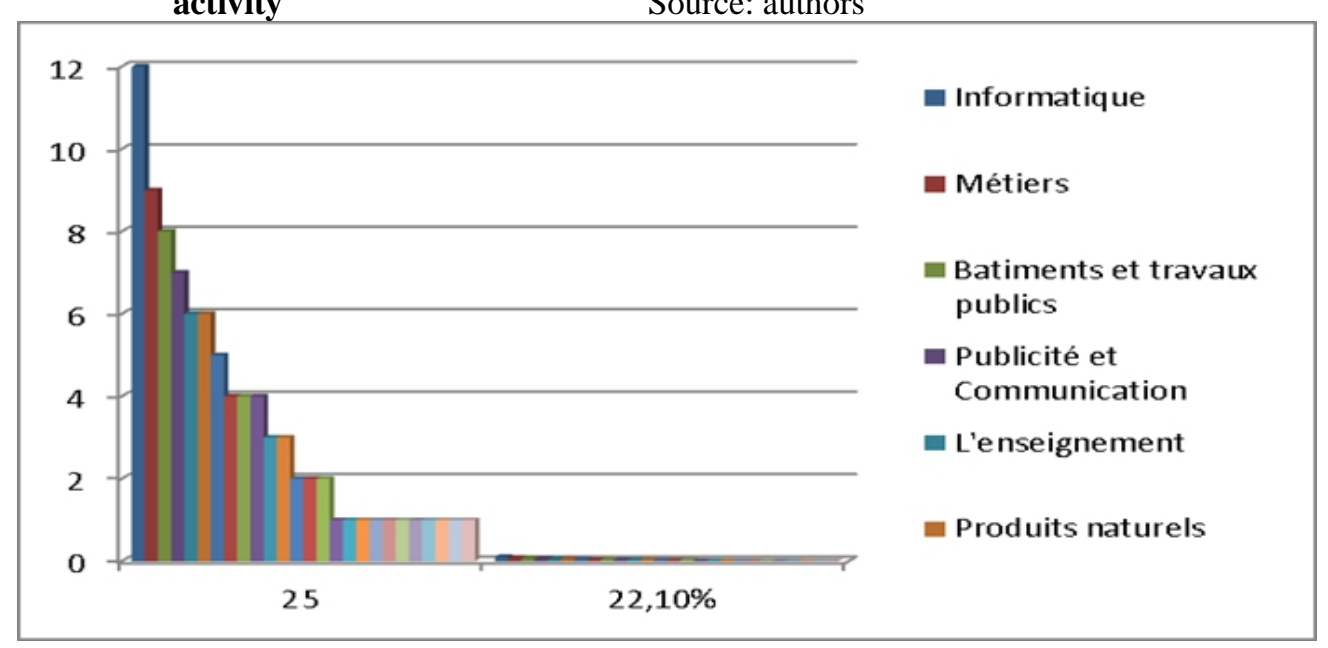

\section{The division by the relationship between the education level and the} entrepreneurial activity

Our study focused on the relationship between the education level and the entrepreneurial activity. In this context, $\mathbf{6 1 . 9 \%}$ of the interviewees proved the existence of this link. This link reflects the willingness and desire to capitalize on the investment they made upstream of the education and training system. 


\begin{tabular}{|l|l|l|}
\hline $\begin{array}{l}\text { Education and } \\
\text { entrepreneurial activity }\end{array}$ & Numbers & Frequency \\
\hline Yes & 70 & $61,9 \%$ \\
\hline No & 40 & $35,4 \%$ \\
\hline None & 3 & $2,7 \%$ \\
\hline Total & 113 & $100 \%$ \\
\hline
\end{tabular}

Source: authors

Figue5: The division by the relationship between the education level and the entrepreneurial activity

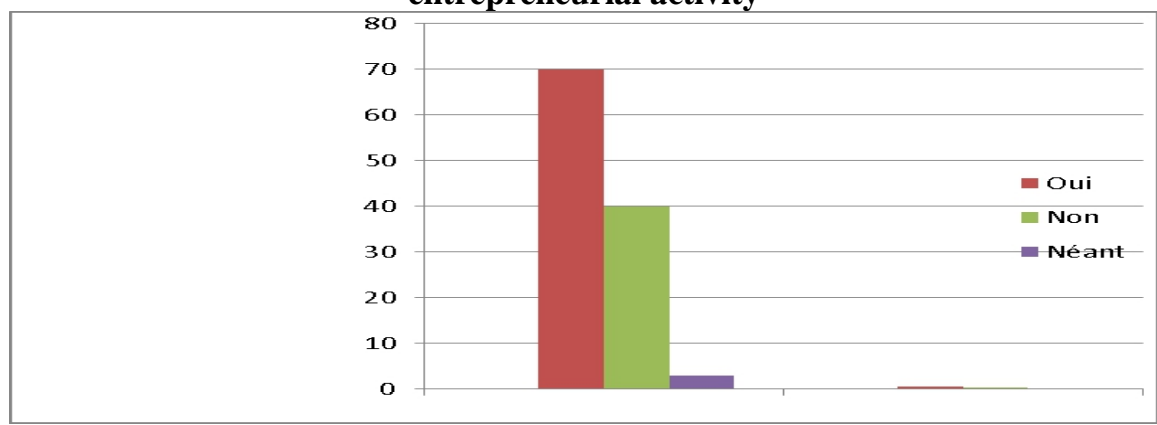

\section{The Division by influence of entrepreneur's environment}

Regarding the activity by family members of the surveyed entrepreneurs, the results show that most of the interviewees are surrounded by entrepreneurs in their families, with a representative percentage of $\mathbf{4 7 . 8 \%}$.

\begin{tabular}{|l|l|l|}
\hline $\begin{array}{l}\text { Company Establishment by } \\
\text { family members }\end{array}$ & Numbers & Frequency \\
\hline Yes & $\mathbf{5 4}$ & $\mathbf{4 7 , 8 \%}$ \\
\hline No & 39 & $\mathbf{3 4 , 5 \%}$ \\
\hline None & 20 & $17,7 \%$ \\
\hline Total & 113 & $100 \%$ \\
\hline
\end{tabular}

Source: authors

Figure 6. The Division by influence of entrepreneur's environment

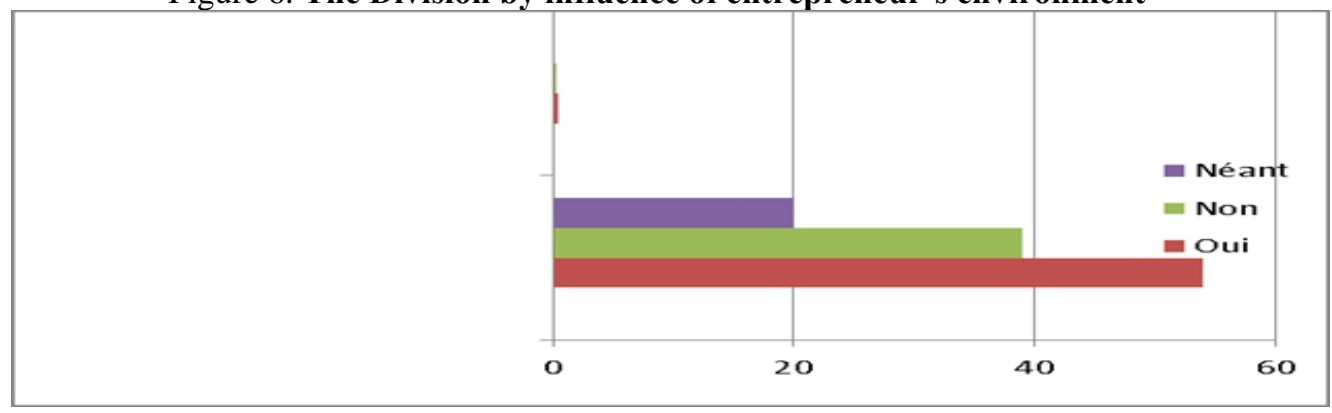

\section{The division by the company funding source}

The examination of the company's capital origin surveyed shows that 63.7\% declared that it exhaled from their own funds, the one whose origin is the family financial support (family loan + Family financial support) $33.7 \%$, 
the source from a bank loan represents $31.9 \%$, and the source from the business angels is a small percentage of $8.8 \%$.

\begin{tabular}{|l|l|l|}
\hline Funding source & Numbers & Frequency \\
\hline Own funds & 72 & $\mathbf{6 3 , 7 \%}$ \\
\hline Bank loans & $\mathbf{3 6}$ & $\mathbf{3 1 , 9 \%}$ \\
\hline Family financial support & 16 & $\mathbf{1 4 , 2 \%}$ \\
\hline Family loan & $\mathbf{2 2}$ & $\mathbf{1 9 , 5 \%}$ \\
\hline Business angels & 10 & $\mathbf{8 , 8 \%}$ \\
\hline Total & 113 & $\mathbf{1 0 0 \%}$ \\
\hline
\end{tabular}

Figure 7. The division by the company funding source

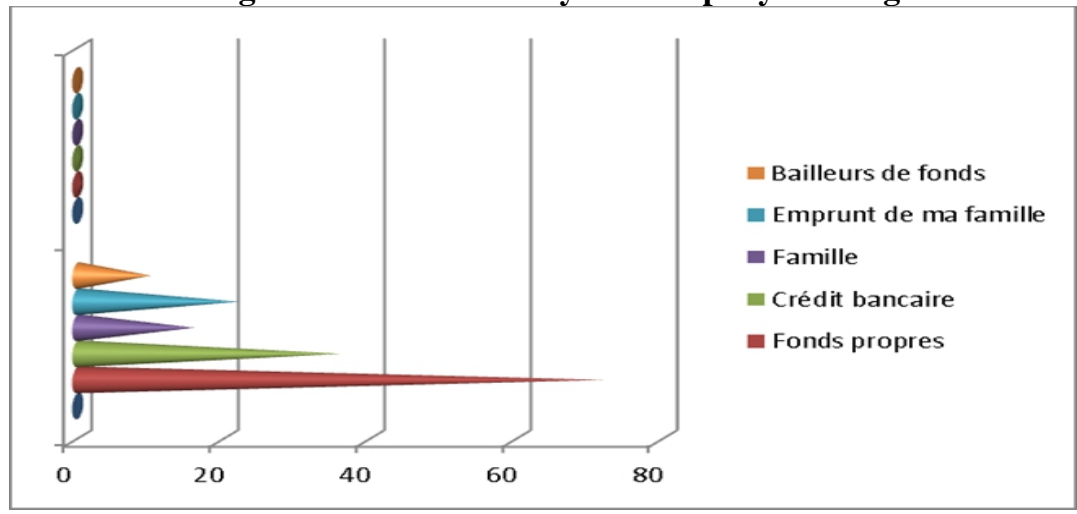

\section{The division by the main difficulties encountered by the entrepreneur}

The main obstacles breaking the development of companies or driving entrepreneurs to drop off or forsake their projects are four:

-insufficient authority or influence over funding agencies to unlock or to unfreeze funding difficulties with $38.1 \%$.

-the inadequacy of the profile of the companies' owners to the demands of the market, open-mindedness with successive voluminal percentages of $43.4 \%$ and $28.3 \%$ for human problems.

-the issuance of authorizations, especially if the activity requires authorization at central government level with a high percentage of $31 \%$.

\begin{tabular}{|l|l|l|}
\hline Difficulties & $\begin{array}{l}\text { Numbers } \\
\text { mentioned }\end{array}$ & Frequency \\
\hline Related to funding & 43 & $\mathbf{3 8 , 1 \%}$ \\
\hline Related to the market & 49 & $\mathbf{4 3 , 4 \%}$ \\
\hline Human ressources & 32 & $\mathbf{2 8 , 3 \%}$ \\
\hline Legal & 35 & $\mathbf{3 1 , 0 \%}$ \\
\hline None & 11 & $\mathbf{9 , 7 \%}$ \\
\hline Total & 113 & $\mathbf{1 0 0 \%}$ \\
\hline
\end{tabular}

Source: authors 
Figure 8 . The division by the main difficulties encountered by the entrepreneur

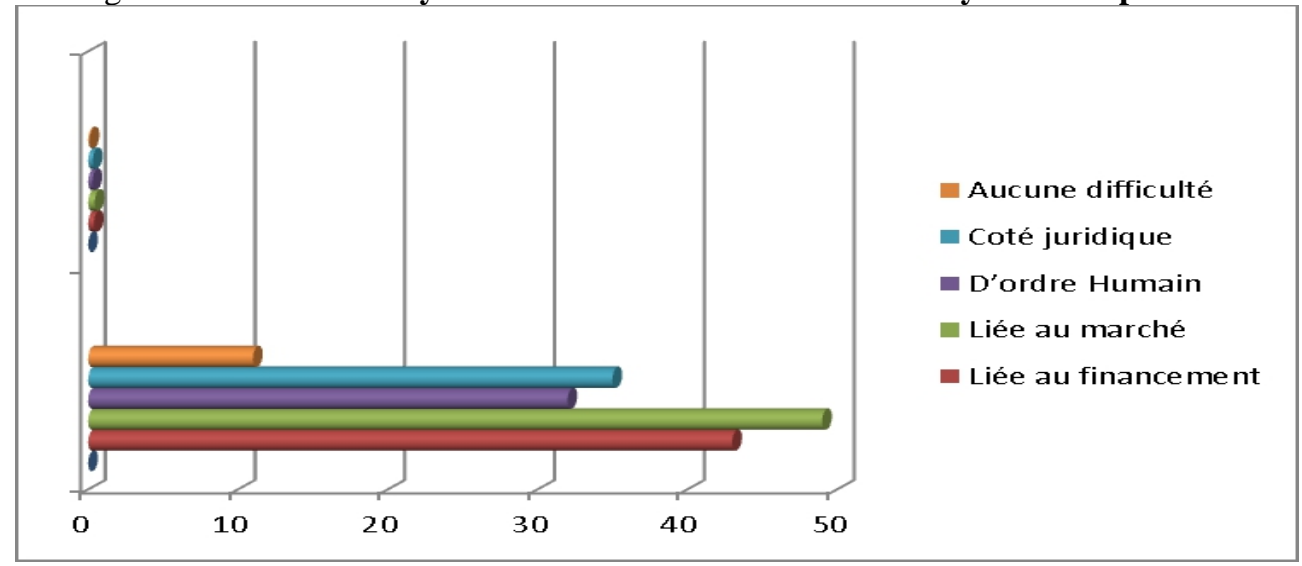

\section{Conclusion: Research and survey Results}

First of all, the interest of this research emanates from its ability to fill a theoretical gap, as few studies have been carried out on the Profile of the Moroccan Entrepreneur.

The survey, conducted among a representative sample of 113 business leaders and entrepreneurs, highlights findings related to the microeconomic aspects of the behavior of the new generation of businesses and entrepreneurs in Morocco, in particular the sociodemographic profile of this generation of elitist entrepreneurs, the major characteristics of their companies, the major changes they are experiencing as well as their vision of the future, and thus by estimating to somehow reflect the actual situation of the companies run by the entrepreneurs of this new called Elitist Entrepreneurs.

At the end of this study, We have sketched out a typical quasi-ideal model of the new generation of entrepreneurs "The elitist entrepreneur." It would be pretentious to answer in the affirmative as the realities of entrepreneurship in Morocco are complexity as We have been able to show from the analysis of the paradoxes of Moroccan capitalism and the state of the places of the companies and so the sample of the investigation that We realized does not allow a scientific generalization. These precautions being based, however, on the basis of the survey data, We can trace the main trends in the profile of the Moroccan entrepreneur belonging to the new generation, especially the one evolving in the structured and modern national production system.

This profile has the following characteristics:

- He is male.

- He is a graduated entrepreneur, Bachelor's degree holder.

- Companies surveyed are present in services, IT, trades, buildings and public works, advertising and communication and education. 
- The activity carried out in the company is linked to the nature of its training.

- It remains, however, still tied to the family network even if kinship does not have much effect.

- It draws the source of its Capital from personal savings and the support of bank borrowings.

- The Main difficulties encountered by the Moroccan Entrepreneur are related to the Market.

We consider that our work is a first step in clearing the "ground" for other researchers. We have tried to answer the question presented in the introduction to this paper. Our main concern was to shed light on "The Profile of the Moroccan Entrepreneur". A laborious statistical work where the documentary deficit is striking.

Morocco has made tremendous progress in promoting and supporting business start-ups, but barriers persist in terms of access to finance and improved business creation.

According to a survey of 113 entrepreneurs and entrepreneurs in Morocco, financing mechanisms are perceived as a major constraint to entrepreneurial development.

\section{* Guideline maintenance limits}

A very little room for maneuver for the respondent. There is little room for speech initiative, expression, since the respondent will just be content to answer the question, without going any further. It can be interesting to test a questionnaire to be sent later (make a pre-test).

\section{* Research limits}

Far from being perfect, this work tried to highlight certain aspects of the profile of the Moroccan Entrepreneur.

- We note the regret not to deepen, the variables related to the psychology of the Moroccan entrepreneur, which is due to a lack of information collected on the ground.

- The basic survey traces a static vision of the phenomenon of the Moroccan entrepreneur, so the lack of historical studies deprives us of tracing an evolution in time.

- The lack of statistics and field researches prohibited us to get more and crucial informations.

\section{References:}

1. Auerswald, P. (2015). Enabling Entrepreneurial Ecosystems: Insights from Ecology to Inform Effective Entrepreneurship Policy. Kauffman Foundation. 
2. Bayt.com. 2016. Top Cities in the Middle East and North Africa Survey.

3. Bayt.com. November 2015. Entrepreneurship in the Middle East survey.

4. Calenda, C. 2016. Annual Report to Parliament on the implementation of legislation in support of innovative startups and SMEs. Ministry of Economic Development, Italy.

5. Compass. 2015. The Global Startup Ecosystem Ranking.

6. GUERRAOUI,D and AFFAYA, N (2009). L'élite économique marocaine, Etude sur la nouvelle génération d'entrepreneurs, Edition l'Harmattan.

7. Enquête du CJD 2009, L'entrepreneuriat au Maroc / Etude de MarchéRapport synthèse Juin.

8. Ernst \& Young. 2014. Cleantech Survey Report: Middle East and North Africa. 4th edition.

9. European Bank for Reconstruction and Development, European Investment Bank, and The World Bank. 2016. What's holding Back the Private Sector in MENA? Lessons from the Enterprise Survey: 124.

10. European Commission. 2016. "A Thriving Private Sector at the Heart of an Inclusive Society."

11. Global Entrepreneurship Monitor. 2015. The Entrepreneurial Dynamics in Morocco.

12. Global Entrepreneurship Monitor. 2015. Women's Entrepreneurship.

13. HSBC Private Bank. 2016. The Essence of Enterprise Development.

14. International Finance Corporation (IFC). 2016. Climate Investment Opportunities in Emerging Markets.

15. Info Dev. 2014. Building Competitive Green Industries.

16. Info Dev. 2016. High-Growth Entrepreneurship: a Preliminary Literature Review.

17. International Energy Agency. 2014. Morocco 2014.

18. International Labor Organization. 2014. Key Indicators of the Labor Market database.

19. International Renewable Energy Agency. 2016. Renewable Energy Auctions.

20. Kingdom of Morocco. 2012. National Sustainable Development Strategy.

21. Klapper, L. Parker, S. 2011. "Gender and the Business Environment for New Firm Creation.” World Bank Research Observer Vol. 26, No. 2: $237-57$.

22. Mckinsey Global Institute.(2015)The power of parity: How advancing women's equality can add $\$ 12$ trillion to global growth. 
23. Organization for Economic Co-operation and Development (OECD)( 2014)

24. Implementation of the "Small Business Act" for Europe in the Mediterranean Middle East and North Africa 2014. SME Policy Index: 41.

25. Oxford Business Group. 2015. "Morocco sets bold targets to boost renewable energy generation capacity." Energy \& the Environment. Report: Morocco 2015.

26. Pew Charitable Trusts. 2015. Power Shifts: Emerging Clean Energy Markets.

27. Sitra. 2015. Green to Scale: Low-carbon success stories to inspire the world.

28. United Nations Economic Commission for Africa. 2014. The Green Economy in Morocco.

29. United States Agency for International Development (USAID). 2012. Morocco Economic Competitiveness, Entrepreneurship.

30. United States Census Bureau. 2010. Small Business Association: Update 2002- 2010.

31. United States Export Agency. 2016. Morocco Country Commercial Guide.

32. WAMDA. 2016. MENA's Cleantech startups: unlocking the path to scale and solve environmental challenges.

33. World Bank Group. 2014. Country Partnership Strategy: Morocco 2014-2017.

34. World Bank Group. 2016. Divergences and Risks. Global Economic Prospects, June 2016.

35. World Bank. 2017. Doing Business: Morocco.

36. World Bank. 2012. Kingdom of Morocco, Promoting Youth Opportunities and Participation.

37. World Bank Group. 2016. Trade and Competitiveness Monitoring Note: Morocco.

38. World Future Council. 2015. 100\% Renewable Energy: Boosting Development in Morocco. 